\title{
Seasonal fluctuations and changing characteristics of a temperate zone wetland bird community
}

\author{
Soo-Dong Lee ${ }^{1}$ and Hyun-Kyung Kang ${ }^{2^{*}}$
}

\begin{abstract}
Background: The composition of wild bird populations in temperate zones greatly varies depending on phenological changes rather than other environmental factors. Particularly, wild birds appearing in wetlands fluctuate greatly due to the crossover of species arriving for breeding during the summer and for wintering. Therefore, to understand the changes to species composition related to phenology, we conducted this basic analysis of populations to further the cause of the protection of wetland-dependent wild birds.

Methods: It is wrong to simply divide a wild bird population investigation into seasons. This study identifies species composition and indicator species that change along with seasons. Wetlands to be surveyed are protected by natural monuments and wetland inventory and are in a state close to nature. In order to identify as many species as possible in wetlands, a survey was conducted in both shallow and deep wetlands. The water depth varied in these areas, ranging from 0.2 to $2.0 \mathrm{~m}$, allowing for both dabbling and diving ducks to inhabit the area. Surveys were conducted using line-transect and distance sampling methods and were conducted at intervals of 2 weeks. The survey was conducted under the following three categories: the eco-tone and emergent zone, the submergent zone, and the water surface. The survey was conducted along a wetland boundary by observing wild birds. A PC-ord program was used for clustering, and the SAS program was used to analyze the changes in species composition. The data strongly indicates that day length is the main factor for seasonal migration periods, despite the fact that climate change and increasing temperatures are often discussed.

Results and conclusions: The indicator species for determining seasons include migrant birds such as Ardea cinerea, Alcedo atthis, Anas penelope, and Poiceps ruficollis, as well as resident birds such as Streptopelia orientalis and Emberiza elegans. Importantly, increases in local individual counts of these species may also serve as indicators. The survey results of seasonal fluctuations in temperate zones shows that spring (April to June), summer (July to September), autumn (October), and winter (November to March) are clearly distinguishable, even though spring and summer seasons tend to overlap, leading to the conclusion that additional research could more clearly identify fluctuation patterns in species composition and abundance in the study area.
\end{abstract}

Keywords: Indicator species, Seasonal fluctuation, Wetland bird community, Temperate zone, Species composition, Seasonal migration periods, Climate change

\footnotetext{
* Correspondence: hkkang@smu.ac.kr

${ }^{2}$ Department of Environment and Landscaping, Sangmyung University, 31

Sangmyungdae-gil, Dongnam-gu, Cheonan-si, Chungcheongnam-do 31066

South Korea

Full list of author information is available at the end of the article
}

(c) The Author(s). 2019 Open Access This article is distributed under the terms of the Creative Commons Attribution 4.0 International License (http://creativecommons.org/licenses/by/4.0/), which permits unrestricted use, distribution, and reproduction in any medium, provided you give appropriate credit to the original author(s) and the source, provide a link to the Creative Commons license, and indicate if changes were made. The Creative Commons Public Domain Dedication waiver (http://creativecommons.org/publicdomain/zero/1.0/) applies to the data made available in this article, unless otherwise stated. 


\section{Introduction}

The impact of global warming has increased spring temperatures in temperate zones and shifts phenological timing forward at a rate of 3.5 days each decade since 1960 (Harrington et al. 1999; Root et al. 2003). Seasons arrive 1 to 9 days earlier, with wild bird species arriving at the breeding ground a day earlier along with an increase of $1^{\circ}$ in temperature (Beaumont et al. 2006; Marica et al. 2005). However, it has been suggested that movement periods of wild birds vary not only due to temperature increases influenced by climate change, but also by resource availability, reproduction processes (Blake et al. 1994), adult or chick presence (Bregnballe et al. 1997), and seasonal changes in vegetation (Anderson et al. 1981). In particular, since reproduction, molting, and seasonal migration are closely related to the length of day and require significant energy, these activities display latitudinal variation (Dixit and Singh 2011). Furthermore, since species compositions and abundance vary before and after migration (Selmi and Boulinier 2003), it becomes necessary to perform repeat surveys across all seasons to reduce error (Weller 2012). However, due to limitations on the length of survey periods (Bibby et al. 2000), there remains a need for a guideline on survey periods by location (Svensson 1978; New Mexico Department of Game and Fish 2010). Ultimately, since species composition and abundance vary seasonally, necessity demands that surveys be performed taking into account seasonal change and identifying indicator species that reveal information about seasonal changes.

Wild bird survey results vary based on the individual surveyor, environment, and characteristics of individual species (Anderson 2001, 2003). Excluding the surveyor and the characteristics of individual species, it is important to match the seasons with respect to the environment and a specific period within the season, as well as the time of day (Cyr and Larivee 1980; Mackenzie et al. 2002; Selmi and Boulinier 2003; McCallum 2005). Also, because long-term monitoring must observe species conditions, conservation priorities, and response or non-response to maintenance activities (Dunn et al. 2006), it is important to select a representative period (McCallum 2005). However, because variations can occur due to external factors other than climate change (Svensson 1978), it is suggested that controllable parts during sampling be representative and that errors be reduced by means of repeat surveys (Nichols 1992; Dunn et al. 2006). As a result, since the effects of climate change cannot be ignored as they relate to seasonal change, it becomes necessary to identify and categorize local factors of effect as well.

On the other hand, wild bird population fluctuations can be measured with regard to land-use variations and are sometimes used for environmental effect evaluations
(Bibby et al. 2000). This practice was initiated when the absence of indicator species suggested that such effects were occurring (Nally 1997). As an indicator species, individual species of wild birds represent the responses of other species within the habitat or group (Canterbury et al. 2000). However, while certain species may appear together, each species will have different habitat needs, as well as life histories, and therefore may respond independently to environmental factors. Thus, individual species cannot be used to make predictions for the entire group (Martin and Li 1992; Martin 1993, 1995), serving instead as indicators of specific environmental variations (James et al. 1984). Habitat information critical for conservation is necessary to obtain for those wetland-dependent birds that require wetlands for survival; such information serves as an important factor in demonstrating the quality of particular wetlands (Wetland International 2010). In addition to fulfilling the essential function of improving the biodiversity of wetlands, wetland birds are sensitive to habitat disturbances and thus can be utilized as biological assessment indicators (Nsor and Obodai 2014). Since species composition will change in response to variations in seasonal factors (Canterbury et al. 2000), wetland birds may be used to determine changing trends in the environment (Buckland 2006). Fluctuations in wild bird species composition as well as abundance in the wetlands occur as a response not only to internal environmental factors, but also to external factors (Svensson 1978). Therefore, if seasonal fluctuations and indicator species representing such variations can be identified, this presents the potential to determine appropriate survey periods for monitoring the quality and health of wetland environments.

Seasonal changes are distinct in temperate zones, where wild birds migrate northward and southward driven by daylight cycles (Misra et al. 2004; Dixit and Singh 2011; Cherry et al. 2013). Wild bird migration occurs in the northern hemisphere in the spring and autumn seasons (Richardson 1990). Recognizing the distinctions between the migratory periods is important because it determines the composition and abundance of species. Therefore, this study will use yearly surveys to identify seasonal fluctuations, characteristics with regard to species composition, and indicator species that may be used to understand seasonal differences.

\section{Methods}

Study area selection and overview of present conditions The Daepyeong and Jilal wetlands are located adjacent to the Nakdong River, one of the four great rivers of South Korea. The distance between the wetlands is approximately $2 \mathrm{~km}$ (Fig. 1 ). 


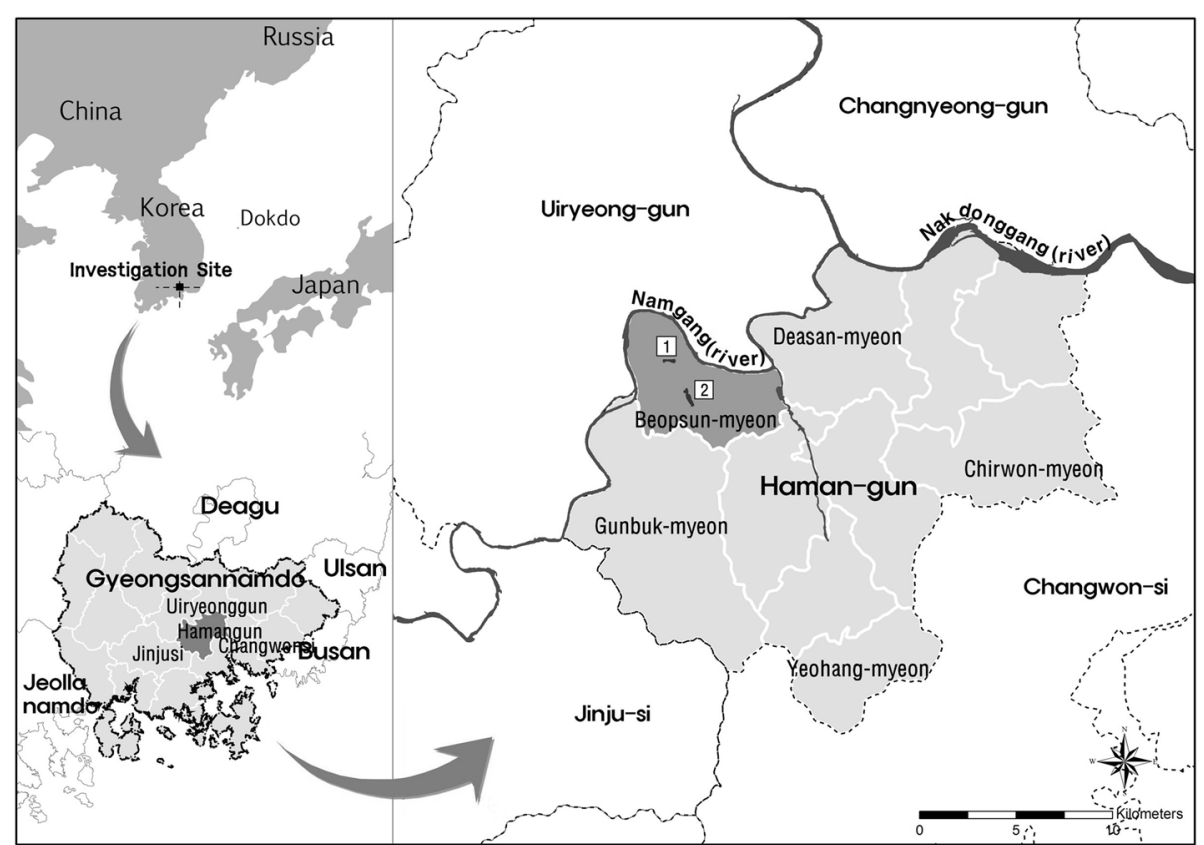

Fig. 1 Survey site location. Daepyung and Jilal wetlands are located between Namgang and Nakdonggang. Symbols represent the following: 1, Daepyong wetland; 2, Jilal wetland; dotted line, provincial boundary

These wetlands represent 1 of 10 wetland locations in a wetland roadmap as designated by Gyeongsangnamdo Province; nationally designated natural monument species such as the Euryale ferox and Cygnus cygnus appear in this location, demonstrating the biodiversity of the area (Lee 2009). Particularly, since the area is surrounded by forests and is close to agricultural lands, this location presents an important wintering area for nationally designated monument species, including Cygnus cygnus, Anas formosa, Anser fabalis, and Anser cygnoides, among other internationally endangered species (Scott 1989; Kar 2013). Although the two wetlands surrounded by forests are adjacent to each other, each one possesses differing ecological characteristics. The Daepyong wetland (a 10 ha area) is covered by water (20\%), floating-leaf and submergent plants (53\%), and emergent plants (27\%). The water depth varies, extending from 0.2 to $2.0 \mathrm{~m}$, allowing for both dabbling and diving ducks to inhabit the area. On the other hand, the Jilal wetland (an 18-ha area) surface consists of floating-leaf and submergent plants (30\%), and emergent plants $(70 \%)$. In this wetland, the water depth varies between 0.0 and $0.6 \mathrm{~m}$, with mud being exposed in the spring and autumn, which allows waders (Scolopacidae) as well as Anser fabalis and Anser cygnoides to appear before and after the spring migratory periods (Fig. 2). There are as many as 87 species of wild birds appearing in these two wetlands, which is approximately $23 \%$ of all wild birds that appear in Korea (Lee and Kim 2010).

\section{Data collection}

Following Watson's method (Watson 2003), the sampling method was applied to the same area, with line-transect and distance sampling, as well as survey period gaps; areas were regularly visited on the 1st and 15th day of each month, with the survey finishing within $2 \mathrm{~h}$. These rules were implemented to satisfy the requirements of a standardized search, and in order to avoid overlapping survey zones and populations. Additionally, following the recommendations of Drapeau et al. (1999) and Palmeirim and Rabaça (1994), mornings were chosen to minimize the effects of the time of day on the abundance and composition of detected birds. However, it is difficult to equally identify all species within the limited timeframe of high sighting probabilities. In selecting the research time of day, it is desirable to focus on common species rather than rare species such as raptors (Järvinen et al. 1977; Robbins 1981). To produce sound survey results, standardization methods such as 2-week intervals and 2-h surveys were applied, as suggested by other researchers (Verner and Ritter 1986).

Observation of the two wetlands was performed following the recommendations of Chen et al. (2011) and Blake (1992), at 7 o'clock in the morning during the spring, summer, and autumn, while Lowther's (1975) suggestion of 8 o'clock in the morning was followed during the winter, recognizing that there is an hour delay in sunrise during the winter months. Sunrise and sunset times are based on data provided by the Astronomy Space Knowledge Site (http:// www.kais.re.kr/kor/index). Also, the recommendations of 


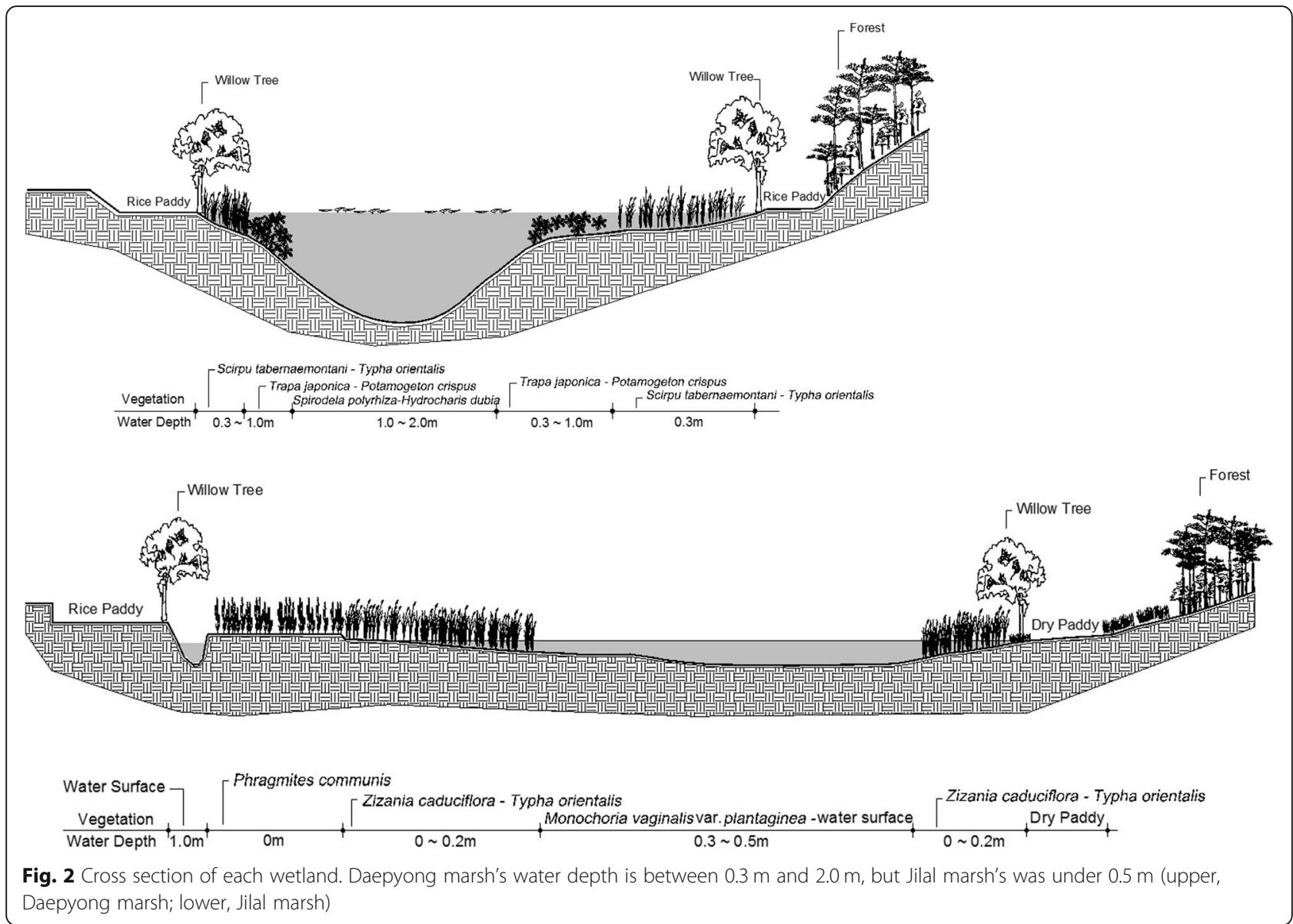

Best (1981), Verner and Ritter (1986), and Marsden and Symes (2008) were also noted: natural, extreme weather conditions such as rain and heavy fog were accounted for and avoided accordingly.

Line-transect surveys were conducted 48 times between January 2011 and December 2012. Based on the results of Kim et al. 2013 study about seasonal optimal survey timing for wild birds, the surveys were conducted over a 2-h period after sunrise. The survey methods were based on suggestions by Oliveira (1998), that speed, efficiency, accuracy, and reproducibility should be prioritized, which is why the line-transect method was applied. To avoid disturbing wild birds in the wetlands, the survey was executed along the wetland boundary of about $2 \mathrm{~km}$ within 8 selected points. Specifically, two teams split from the central location and conducted the survey separately using the line-transect method. It was deemed necessary to set up detailed or separate plots to avoid duplicating the wild bird counts and areas (Savard and Hooper 1995). In areas where the wetland can be easily observed, the researchers stayed in place for about 20 min identifying the wild bird species.

The actual surfaces of the two wetlands are composed of water and vegetation, such as floating-leaf and submergent plants, as well as emergent plants. Accordingly, the survey was executed under the following three categories: the eco-tone and emergent zone, the submergent zone (including the floating-leaf areas), and water surface. Surveys of the eco-tone and emergent zone, which facultative or wetland-dependent species prefer, were implemented using the line-transect method along the riverside (Bibby et al. 2000). Surveys in the water surface zone and submergent plants zone, where wetland-dependent species may be observed, were executed using the line-transect method, which included 20-min stops at 8 points (Bibby et al. 2000; McCallum 2005) (Fig. 3).

\section{Data analysis}

To compare the relative dominance of emerging species based on the transect data, the importance percentage (IP) (Brower et al. 1977) was analyzed as a percentage by integrating the importance value of Curtis and McIntosh (1951) for comparison. The IP was calculated as (relative density + relative frequency)/2. Relative density (RD) is the number of a specific species relative to the total number of occurrences, and relative frequency (RF) is a percentage of the frequency of all species. 

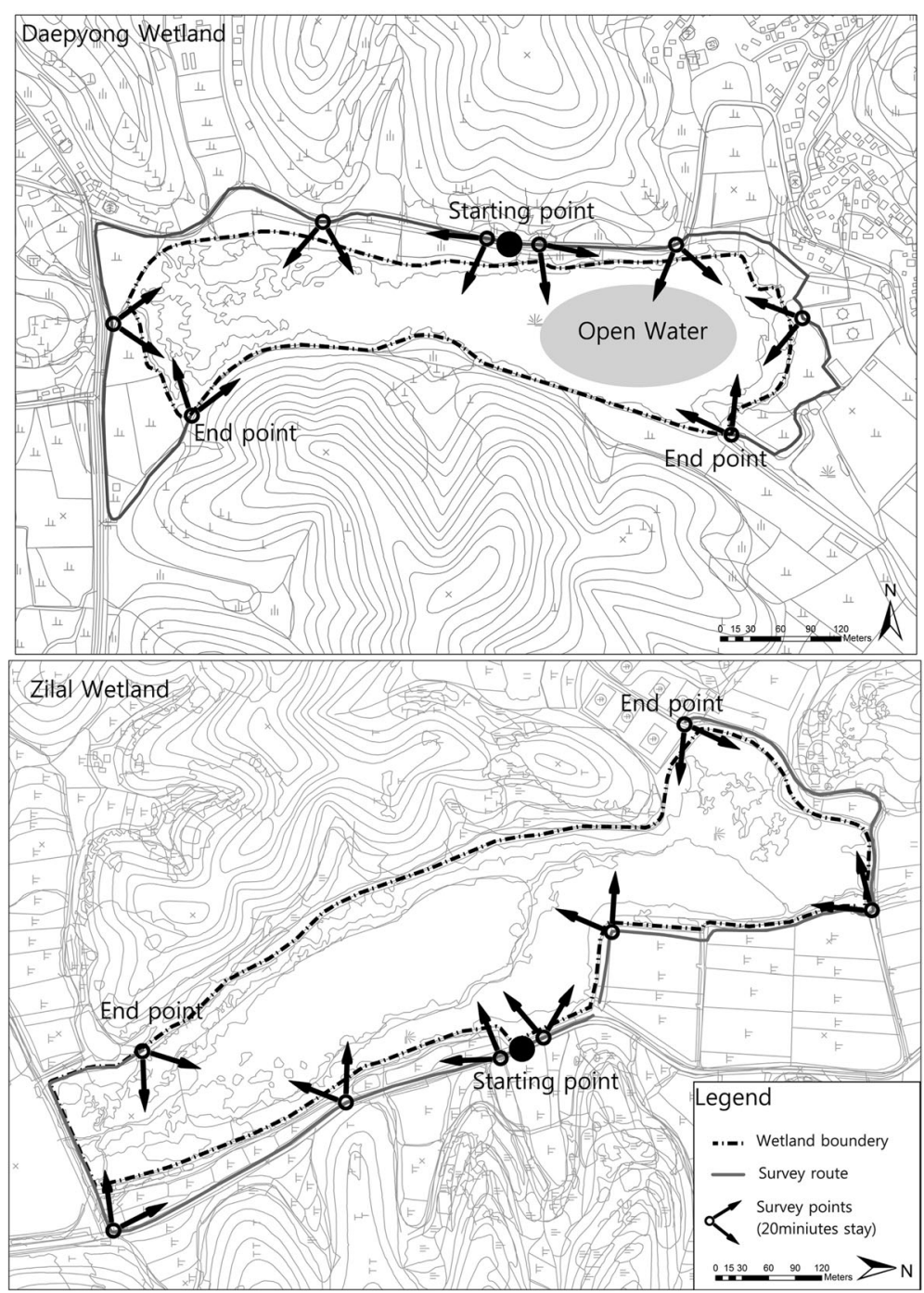

Fig. 3 The survey route map. Line-transect was placed at the wetland boundary of about $2 \mathrm{~km}$ within 8 points in each wetland. Two teams split from the center; the researchers stayed in place for about $20 \mathrm{~min}$ at survey points

Aside from the above, categorization of each research incidence can be separated into the classification method and the ordination method. Since 1990, classification and ordination methods have been used together to perform increasingly thorough research on colony categorization (communities classification) and environmental relationships. The classification was performed using the TWINSPAN (TWo-way INdicator SPecies ANalysis) classification method, which is similar to the Braun-Blanquet table analysis, a species categorization method. To display the overall importance of each species in each research as above each year's IP was analyzed and compared (Curtis and McIntosh 1951). This study used TWINSPAN and DCA together to perform classifications. Specifically, the data gathered during surveys for TWINSPAN analysis were used to derive relative density, and cut levels were set at $0 \%, 2 \%, 5 \%, 10 \%$, and $20 \%$. Species with over $20 \%$ relative density in each study area were considered to be the dominant species of the survey area. The PC-ORD (MJM Software Design) ver. 4 was used to conduct the TWINSPAN and DCA analyses. To characterize the migratory behavior of a species, we classified each species into one of the following categories: resident, migrant, and migratory birds that pass through a province in spring and autumn.

SAS was used to determine whether seasonal fluctuations in species counts and individual counts were statistically significant. Canonical correlation analysis was used to identify the species that affect the inter-cluster difference and seasonal variation. Using canonical correlation analysis based on partial correlation, we first determined which canonical correlation coefficients-such as raw and standardized-were appropriate. Canonical correlations between the Julian date and species/individual 
count, and their canonical variable were calculated in order to verify the statistical significance of fluctuations in wild bird species composition between seasons. Also, in order to determine factors that may contribute to seasonal migration, correlation tests were conducted between species and environmental factors expected to affect migration time, such as lowest or highest temperature, sunrise and sunset time, and day length. As a result of the analysis, if the value is more than \pm 0.5 , it is considered a factor affecting a change in species composition and so can be used as an indicator species in species correlation. Temperature, sunrise and sunset times, and photoperiod were used as collected by weather observation stations and the astronomical knowledge information site (http://www.kasi.re.kr/kor/index).

To select indicator species of seasonal changes based on correlation analysis for environmental factors, the analysis was performed for correlations between the species and standardized canonical coefficients. As a result, an indicator species that can judge the season based on correlation with temperature, sunrise and sunset time, and photoperiod was selected.

\section{Results}

\section{Season and indicator species}

The results of the canonical correlation analysis show that, out of the five possible computation pairs, the first canonical correlation coefficient showed the highest correlation at 0.995417 (Table 1). The Eigenvalues for the first canonical correlation coefficient all exceeded 1, with values above 1.7280 , which shows statistical significance. However, the proportion of the first value was 0.7861 , indicating an explanatory power of $78.60 \%$, while, on the other hand, the remainders were at a low figure of about $10 \%$. Additionally, when considering $p$ values, only the first canonical correlation coefficient was less than $a=$ 0.05 and statistically significant. Therefore, all relationships are in the first canonical variate. As a result, because species composition (that is, the species and individual counts) vary according to the season, there exists a need to determine avifauna composition in each season. Change of species composition is statistically related to the time of year.
Correlations between environmental factors and their canonical variables displayed a statistical significance for only the first canonical correlation coefficient, and thus the rest were omitted. Further, the results from analyzing factors of species change such as low temperature (0.8066), high temperature (0.8236), sunrise $(-0.2884)$, sunset $(-0.2876)$, and day length $(0.9934)$ reveal that day length affects the migration patterns of wild birds (Table 2). By analyzing correlations between species and their canonical variables and selecting species that are affected at greater than \pm 0.5 . Indicator species for longer day lengths were mostly migratory birds, including Ardea cinerea, Cuculus canorus, Alcedo atthis, Eurystomus orientalis, and Oriolus chinensis. Indicator species for shorter day lengths were migratory birds such as Poiceps ruficollis, Anas penelope, and resident birds such as Streptopelia orientalis, Anthus hodgsoni, Phoenicurus auroreus, Emberiza rustica, and Emberiza elegans. There were four major wetland-dependent species, including Ardea cinerea, Alcedo atthis, Poiceps ruficollis, and Anas penelope, and eight other species attached to the wetlands.

The results of classification according to TWINSPAN and DCA (Figs. 4 and 5) confirm that migratory patterns of wild birds are important considerations for distinguishing seasons. According to DCA, migration seasons were combined into one group. For this reason, the third group was eventually divided into two groups. Actual indicator species include winter birds for group I, resident and migratory birds for groups II and III, and summer birds for group IV. In a comprehensive classification of these groups, group I was classified by Anser fabalis and thus was named the Anser fabalis group, which covers January, February, March, November, and December. Group II did not include Anser fabalis and instead was dominated by Anas poecilorhyncha, for which it was named, covering the month of October. Group III did not include Bubulcus ibis, but is named after the two dominant species, the Paradoxornis webbiana and Anas poecilorhyncha, and respectively covers April, May, and June. Group IV is classified by Bubulcus ibis and is thus named accordingly, covering June, July, August, and September.

Table 1 Canonical correlation analysis based on partial correlations

\begin{tabular}{llllllllllll}
\hline $\begin{array}{l}\text { Canonical } \\
\text { correlation }\end{array}$ & $\begin{array}{l}\text { Adjusted } \\
\text { canonical } \\
\text { correlation }\end{array}$ & $\begin{array}{l}\text { Approximate } \\
\text { standard error }\end{array}$ & $\begin{array}{l}\text { Squared } \\
\text { canonical } \\
\text { correlation }\end{array}$ & Eigenvalue & Difference & Proportion & $\begin{array}{l}\text { Likelihood } \\
\text { ratio }\end{array}$ & $\begin{array}{l}\text { Approximate } \\
F \text { value }\end{array}$ & $\begin{array}{l}\text { Num } \\
\text { DF }\end{array}$ & $\begin{array}{l}\text { Den } \\
\text { DF }\end{array}$ & $\begin{array}{l}p \text { value } \\
0.995417\end{array}$ \\
\hline 0.991720 & 0.001320 & 0.990855 & 108.3457 & 90.8595 & 0.7861 & 0.00000586 & 2.58 & 180 & 44.9 & 0.0002 \\
0.972577 & 0.950673 & 0.007808 & 0.945906 & 17.4862 & 9.7818 & 0.1269 & 0.00064048 & 1.47 & 140 & 38.5 & 0.08 \\
0.940806 & 0.897611 & 0.016582 & 0.885115 & 7.7044 & 8.1476 & 0.0559 & 0.01184002 & 1.03 & 102 & 30.8 & \\
0.847848 & 0.726717 & 0.040581 & 0.718847 & 2.5568 & 0.8287 & 0.0186 & 0.10306012 & 0.07 & 66 & \\
0.795888 & 0.674191 & 0.052909 & 0.633438 & 1.7280 & & 0.0125 & 0.36656230 & 0.65 & 32 & \\
\hline
\end{tabular}


Table 2 Multivariate statistics and $F$ approximations for selecting canonical variables

\begin{tabular}{llllll}
\hline Statistic & Value & Fvalue & Num PF & Den DF & Pr $>F$ \\
\hline Wilks' lambda & 0.00000586 & 2.58 & 180 & 44.962 & 0.0002 \\
Pillai's trace & 4.17416026 & 1.68 & 180 & 60 & 0.0101 \\
Hotelling-Lawley trace & 137.82109421 & 5.26 & 180 & 36 & 12.742 \\
Roy's greatest root & 108.34570413 & 36.12 & 12 & 0.0003 \\
\hline
\end{tabular}

Figure 6 displays fluctuation tendencies within the 87 species observed. The left area shows the winter species, and the right shows the summer species, with resident birds and birds of passage distributed in the center (Fig. 6). The results of this study extended over a span of 2 years with 24 trials in the wetlands, confirming that species composition varies according to seasons. The species composition presented clear distinctions between autumn (October) and winter (November to March), while spring (April to June) and summer (July to September) revealed a tendency to overlap in June. Based on these results, with respect to wild bird species composition, the appropriate survey periods for determining seasonal fluctuations for wetland-dependent species are as follows: April in spring, August in summer, October in autumn, and December to January in winter.

\section{Group characteristics}

An analysis of group species composition, classified into spring, summer, autumn, and winter (Table 3), shows that, for group 1 (winter), Anser fabalis was dominant with an IP 23.08\%; other species included Anas poecilorhyncha (11.14\%), Anas falcate (9.27\%), Paradoxornis webbiana (8.39\%), and Anas platyrhynchos (7.21\%). For group II (autumn), Anas poecilorhyncha was dominant with an importance percent of 37.9\%; other species included Paradoxornis webbiana (7.10\%) and Anas crecca (6.17\%). For group III, Paradoxornis webbiana (12.88\%) and Anas poecilorhyncha (12.42\%) were dominant, while Streptopelia orientalis (5.65\%) and Anas crecca (4.69\%) made up the other major observed species. Group IV was dominated by Paradoxornis webbiana (16.27\%) and Anas poecilorhyncha (13.68\%), with Egretta alba modesta (8.96\%) and Streptopelia orientalis (4.84\%) also making significant appearances.

A comparison was performed for species and individual counts for each group of wild birds, classified according to migratory pattern (Fig. 7). The species for each group showed that there were four groups in which resident birds made up the highest proportion at 55.6 68.8\%. With the exception of resident birds, the migratory patterns most prominent for each group were as follows: birds of passage for group I (25.0\%), winter birds for group II (25.6\%), summer birds for group III (24.4\%), and again, summer birds for group IV (32.0\%). Groups III and IV varied in species composition, yet were similar in that, with the exception of the resident birds, summer birds dominated.

\section{Discussion}

To select an appropriate survey time to investigate the wild bird population is essential in temperate regions where seasonal composition changes are significant. The assumptions of un-validated data affect future development and conservation efforts when based on whether or not certain species are present. Three estimates were possible with regard to seasonal classification in temperate zones. First, the data strongly indicates that day length is the main factor for seasonal migration periods, despite the fact that climate change and increasing

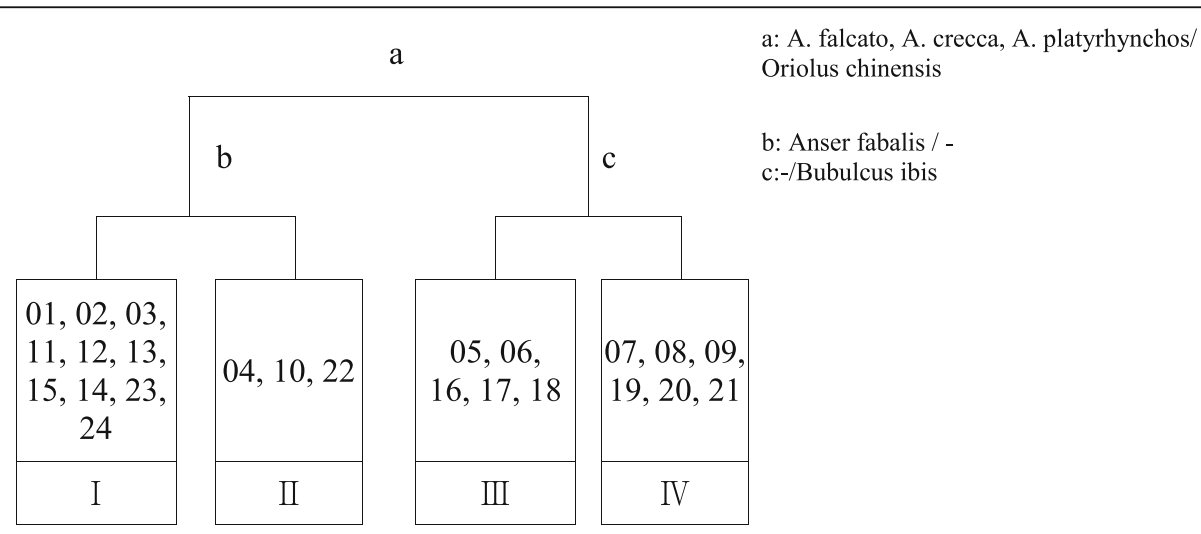

Fig. 4 Dendrogram of 24 plots classified by TWINSPAN classification. Abbreviations are as follows: a, division 1; b, division 2; c, division 3; I, group 1; II, group 2; III, group 3; IV, group 4; number, 01 January 2011 to 24 December 2012 


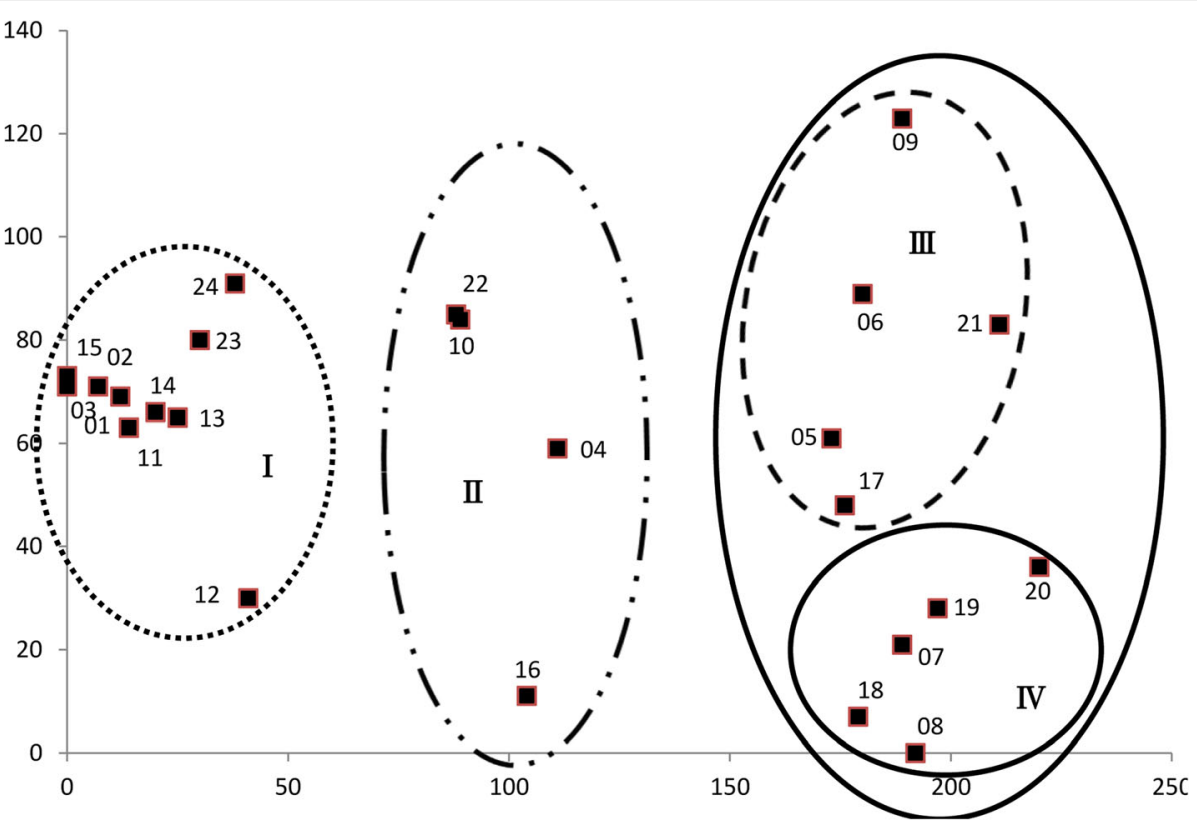

Fig. 5 DCA ordination of the 24 plots. Abbreviations are as follows: number, 01 January 2011 to 24 December 2012. Originally, migration seasons were combined into one group, so the third group was divided into two groups (III, IV)

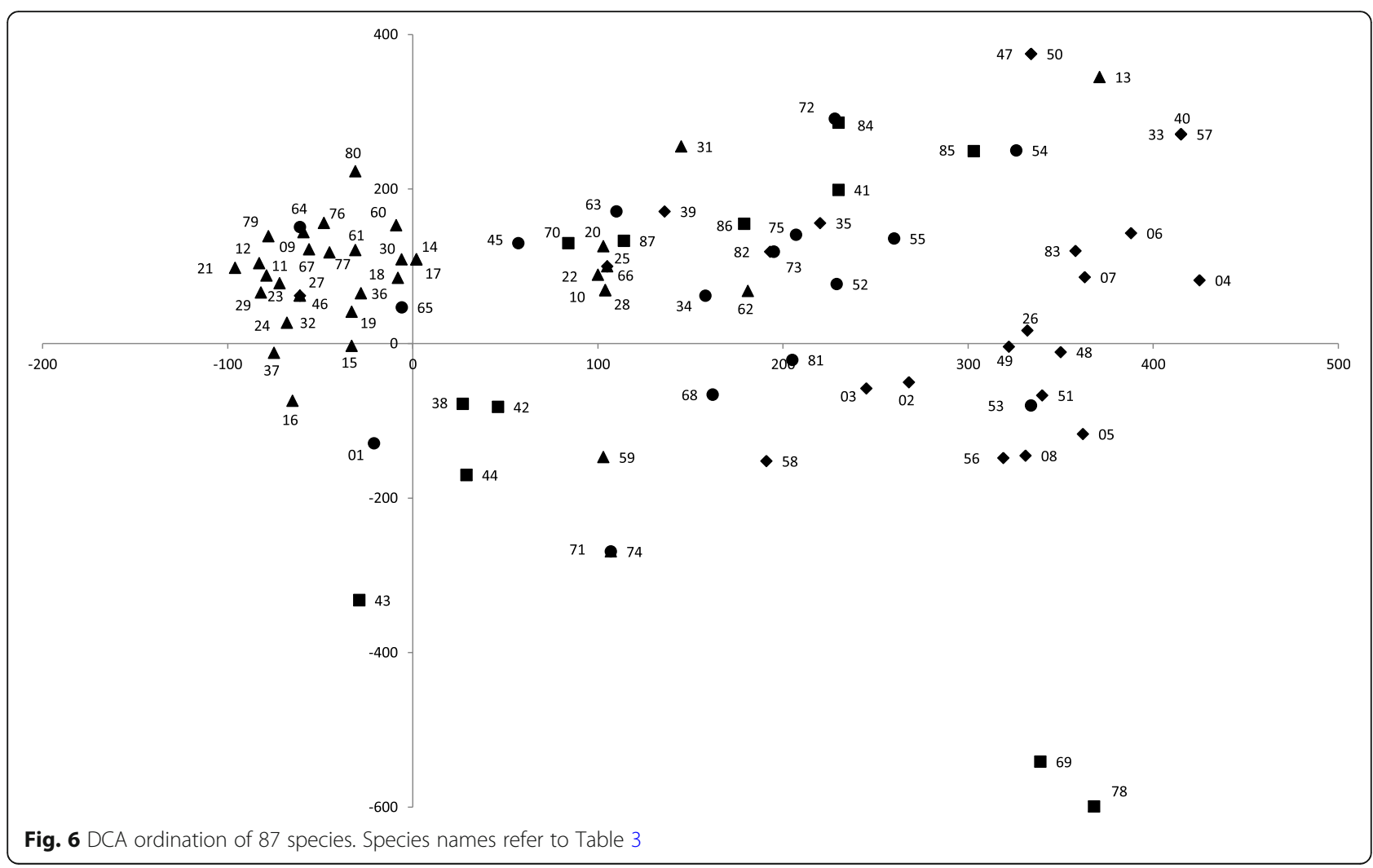


Table 3 Importance percentage of major wild birds in each season

\begin{tabular}{|c|c|c|c|c|c|}
\hline Scientific name & & Winter & Fall & Spring & Summer \\
\hline Poiceps ruficollis & S_01 & 0.18 & - & - & 0.04 \\
\hline Ardea cinerea & S_02 & 0.30 & 0.36 & 2.40 & 1.82 \\
\hline Egretta alba modesta & S_03 & 1.95 & 1.39 & 2.99 & 8.96 \\
\hline Egretta intermedia & S_04 & - & - & - & 2.36 \\
\hline Egretta garzetta & S_05 & - & 0.11 & 0.20 & 0.83 \\
\hline Bubulcus ibis & S_06 & - & 0.19 & - & 2.76 \\
\hline Butorides striatus & S_07 & - & - & 0.14 & 0.17 \\
\hline Nycticorax nycticorax & S_08 & - & - & 0.16 & - \\
\hline Cygnus cygnus & S_09 & 0.60 & - & - & - \\
\hline Anser cygnoides & S_10 & - & - & - & - \\
\hline Anser fabalis & S_11 & 23.08 & - & - & - \\
\hline Anser albifrons & S_12 & 0.01 & - & - & - \\
\hline Aix galericulata & S_13 & - & 0.14 & - & 0.66 \\
\hline Anas penelope & S_14 & 0.01 & 0.05 & - & - \\
\hline Anas falcata & S_15 & 9.27 & 4.43 & 3.05 & - \\
\hline Anas strepera & S_16 & 0.17 & - & - & - \\
\hline Anas formosa & S_17 & - & 0.02 & - & - \\
\hline Anas crecca & S_18 & 5.19 & 6.17 & 4.69 & - \\
\hline Anas platyrhynchos & S_19 & 7.21 & 5.83 & 0.99 & 0.36 \\
\hline Anas poecilorhyncha & S_20 & 11.14 & 37.90 & 12.42 & 13.68 \\
\hline Anas acuta & S_21 & 0.02 & - & - & - \\
\hline Anas clypeata & S_22 & 0.06 & - & - & - \\
\hline Aythya ferina & S_23 & 1.67 & - & - & - \\
\hline Aythya fuligula & S_24 & 0.02 & - & - & - \\
\hline Aegypius monachus & S_25 & 0.01 & - & - & - \\
\hline Accipiter soloensis & S_26 & - & - & 0.22 & 0.06 \\
\hline Accipiter nisus & S_27 & 0.06 & - & - & - \\
\hline Accipiter gentilis & S_28 & - & - & - & - \\
\hline Buteo buteo & S_29 & 0.01 & - & - & - \\
\hline Buteo hemilasius & S_30 & 0.01 & 0.04 & - & - \\
\hline Falco tinnunculus & S_31 & 0.03 & 0.02 & - & 0.06 \\
\hline Falco columbarius & S_32 & - & - & - & - \\
\hline Falco subbuteo & S_33 & - & - & - & 0.06 \\
\hline Phasianus colchicus & S_34 & 0.21 & 0.09 & 0.82 & 0.19 \\
\hline Gallicrex chloropus & S_35 & 0.13 & 1.52 & 0.57 & 0.50 \\
\hline Fulica atra & S_36 & 0.26 & 0.34 & - & - \\
\hline Vanellus vanellus & S_37 & 0.81 & - & - & - \\
\hline Charadrius placidus & S_38 & 0.17 & 0.49 & 0.45 & - \\
\hline Charadrius dubius & S_39 & - & - & 0.62 & - \\
\hline Tringa ochropus & S_40 & - & - & - & 0.03 \\
\hline Tringa glareola & S_41 & - & 0.08 & 0.06 & 0.03 \\
\hline Tringa hypoleucos & S_42 & 0.01 & 0.04 & 0.03 & - \\
\hline Tringa brevipes & S_43 & 0.05 & - & - & - \\
\hline Gallinago gallinago & S_44 & 0.28 & 0.47 & 0.73 & - \\
\hline
\end{tabular}

Table 3 Importance percentage of major wild birds in each season (Continued)

\begin{tabular}{|c|c|c|c|c|c|}
\hline Scientific name & & Winter & Fall & Spring & Summer \\
\hline Streptopelia orientalis & S_45 & 6.98 & 3.30 & 5.65 & 4.84 \\
\hline Cuculus fugax & S_46 & - & - & - & - \\
\hline Cuculus micropterus & S_47 & - & - & 0.06 & - \\
\hline Cuculus canorus & S_48 & - & - & 0.34 & 0.40 \\
\hline Alcedo atthis & S_49 & 0.01 & - & 0.65 & 0.38 \\
\hline Halcyon pileata & S_50 & - & - & 0.06 & - \\
\hline Eurystomus orientalis & S_51 & 0.00 & 0.00 & 0.36 & 0.26 \\
\hline Dendrocopos kizuki & S_52 & 0.10 & 0.04 & 0.58 & 0.28 \\
\hline Dendrocopos leucotos leucotos & S_53 & 0.01 & 0.00 & 0.03 & 0.20 \\
\hline Dendrocopos major & S_54 & 0.00 & 0.05 & 0.19 & 0.07 \\
\hline Picus canus & S_55 & 0.05 & 0.13 & 0.39 & 0.26 \\
\hline Hirundo rustica & S_56 & 0.00 & 0.00 & 1.33 & 1.26 \\
\hline Motacilla cinerea & S_57 & 0.00 & 0.00 & 0.00 & 0.10 \\
\hline Motacilla alba & S_58 & 0.04 & 0.00 & 0.09 & 0.12 \\
\hline Motacilla lugens & S_59 & 0.03 & 0.13 & 0.24 & 0.00 \\
\hline Anthus hodgsoni & S_60 & 0.20 & 0.55 & 0.00 & 0.00 \\
\hline Anthus rubescens & S_61 & 0.71 & 0.00 & 0.36 & 0.00 \\
\hline Hypsipetes amaurotis & S_62 & 1.21 & 2.12 & 3.01 & 2.66 \\
\hline Lanius bucephalus & S_63 & 0.12 & 0.31 & 0.00 & 0.20 \\
\hline Troglodytes troglodytes & S_64 & 0.06 & 0.00 & 0.00 & 0.00 \\
\hline Phoenicurus auroreus & S_65 & 0.28 & 0.58 & 0.00 & 0.05 \\
\hline Turdus pallidus & S_66 & 0.01 & 0.00 & 0.00 & 0.00 \\
\hline Turdus naumanni & S_67 & 0.14 & 0.00 & 0.00 & 0.00 \\
\hline Paradoxornis webbiana & S_68 & 8.39 & 7.10 & 12.88 & 16.27 \\
\hline Phylloscopus borealis & S_69 & 0.00 & 0.00 & 0.00 & 0.03 \\
\hline Phylloscopus coronatus & S_70 & 0.00 & 0.02 & 0.00 & 0.00 \\
\hline Ficedula zanthopygia & S_71 & 0.00 & 0.00 & 0.03 & 0.00 \\
\hline Aegithalos caudatus & S_72 & 0.38 & 0.00 & 3.00 & 0.32 \\
\hline Parus palustris & S_73 & 0.13 & 0.00 & 0.82 & 0.04 \\
\hline Parus ater & S_74 & 0.00 & 0.00 & 0.03 & 0.00 \\
\hline Parus major & S_75 & 0.92 & 1.13 & 3.57 & 1.73 \\
\hline Emberiza rustica & S_76 & 3.20 & 1.16 & 0.00 & 0.00 \\
\hline Emberiza elegans & S_77 & 2.33 & 0.54 & 0.24 & 0.00 \\
\hline Emberiza aureola & S_78 & 0.00 & 0.00 & 0.00 & 0.02 \\
\hline Fringilla montifringilla & S_79 & 1.13 & 0.00 & 0.00 & 0.00 \\
\hline Coccothraustes coccothraustes & S_80 & 0.03 & 0.00 & 0.00 & 0.00 \\
\hline Passer montanus & S_81 & 1.53 & 1.08 & 5.24 & 2.91 \\
\hline Sturnus cineraceus & S_82 & 0.13 & 0.00 & 0.89 & 0.08 \\
\hline Oriolus chinensis & S_83 & 0.00 & 0.00 & 0.84 & 1.44 \\
\hline Garrulus glandarius & S_84 & 0.29 & 0.96 & 0.22 & 1.27 \\
\hline Cyanopica cyanus & S_85 & 0.18 & 0.14 & 0.31 & 1.15 \\
\hline Pica pica & S_86 & 1.08 & 0.74 & 2.42 & 1.68 \\
\hline Corvus macrorhynchos & S_87 & 0.67 & 0.64 & 0.79 & 0.79 \\
\hline
\end{tabular}




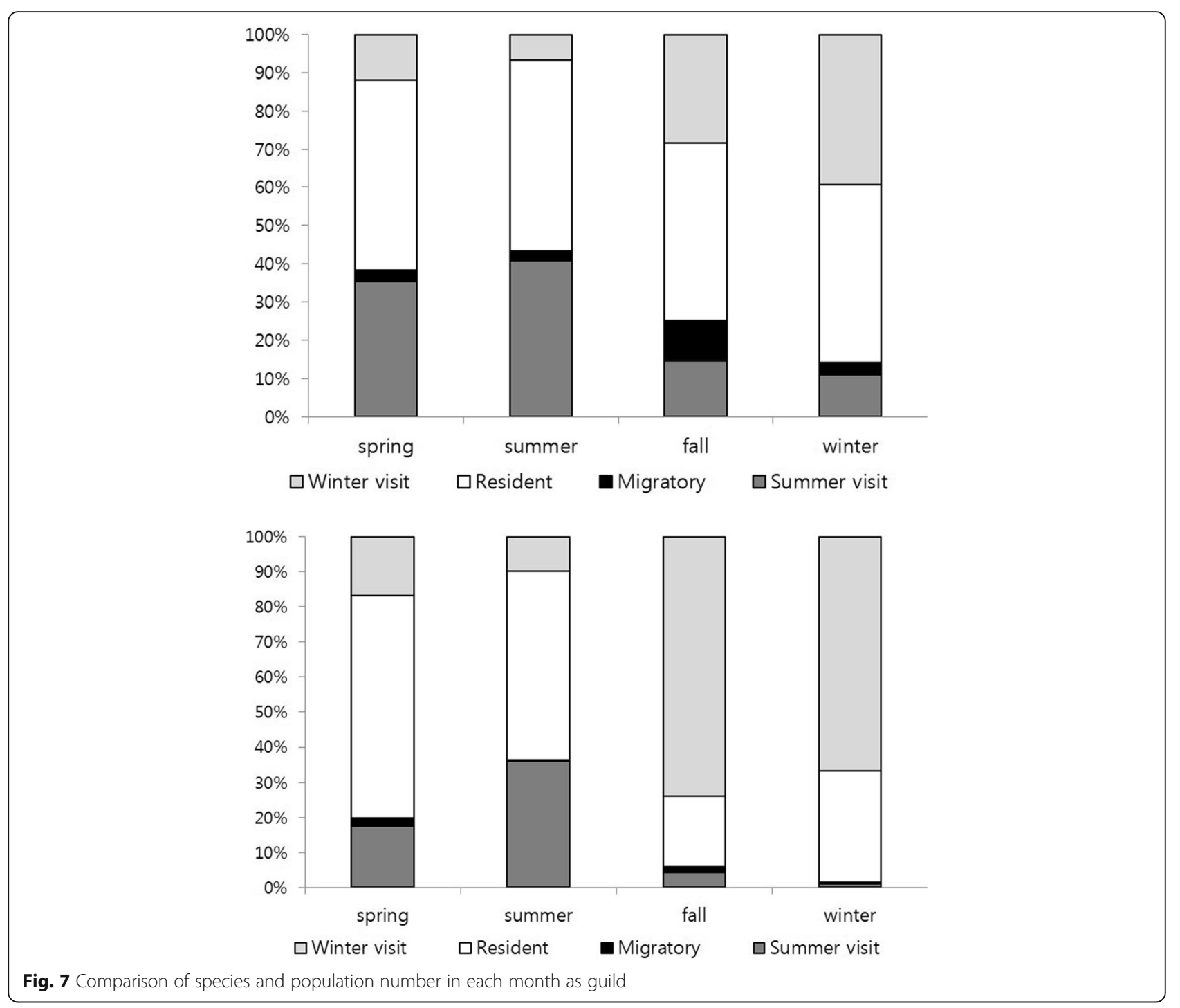

temperatures are often discussed. Second, the indicator species for determining the season include migrant birds such as herons, common kingfisher, European widgeons, and little grebes, as well as resident birds such as Oriental turtledoves and yellow-throated buntings. Importantly, increases in local individual counts of these species may also serve as indicators. Lastly, the survey results of seasonal fluctuations in temperate zones show that spring (April to June), summer (July to September), autumn (October), and winter (November to March) are clearly distinguishable, with the spring and summer seasons tending to overlap, leading to the conclusion that additional research would be helpful to more clearly identify fluctuation patterns of species composition and abundance in the study area during those months.

Wild birds periodically migrate in order to avoid extreme environments, influenced by factors such as rising temperatures (Beaumont et al. 2006; Marica et al. 2005), abundance of resources, seasonal changes (Blake et al. 1994; Scott 2010), and changes in day length (Michot et al. 2006; Dixit and Singh 2011; Cherry et al. 2013). Also, fluctuations in individual groups, caused by the availability of resources, habitat conditions, weather, and breeding cycles, have been shown to be natural phenomena that greatly affect migratory birds traveling long distances (Blake et al. 1994). Generally, wild birds migrate to locations with warmer climates and abundant sources of food in order to survive; factors such as temperature changes (Walther et al. 2002; Cuervo and Møller 2013), yearly changes in day length (Tewary and Dixit 1983), and light conditions (Misra et al. 2004) are equally important in the determination of migration timing. However, it has been said that simple factors, rather than a combination of factors, may cause seasonal fluctuations (Seoane et al. 2013). An analysis of these factors and their effect on species composition and abundance result 
in the conclusion that migration is determined by day length, rather than temperature. This finding corresponds with the studies of Scott (2010) as well as Dixit and Singh (2011), which conclude that day length interacts with birds' biological clocks to determine seasonal changes thereby affecting migration timing. Thus, despite the presence of other factors, day length is shown to be the conclusive factor that affects wild bird migration and seasonal distinctions.

The indicator species represent a single species that illuminates the responses of other species within the group (Canterbury et al. 2000). While varying species may sometimes uniquely respond to environmental changes (James et al. 1984), these indicator species often display similar emergence timing and have the same habitat requirements as other species in the group, thus allowing observers to make predictions for the entire group (Martin and Li 1992; Martin 1993, 1995). Wild birds that rely on wetlands to survive may also change their species composition in response to changes in habitat, food sources, and environmental conditions (Canterbury et al. 2000; Buckland 2006; Wetland International 2010), and are thus suitable selections for indicator species (Nsor and Obodai 2014). Species migration rely on environmental conditions and availability of food sources, and so vary in timing, but that timing generally occurs around spring and autumn (Lefebvre and Poulin 1996). In particular, spring migrations to temperate zones often occur when food is most available (Osbornel and Green 1992; Harrington et al. 1999) and at the beginning of egg-laying season (Both et al. 2006). Thus, migratory birds are most prevalent during this period. The indicator species of this season are the wetland-dependent Ardea cinerea and Alcedo atthis, as well as the wetland-facultative Cuculus canorus, Eurystomus orientalis, and Oriolus chinensis, which are all migratory species. Sparrows and herons, prevalent over the summer, cannot be categorized as indicator species because they arrive early in spring and depart gradually (Underhill et al. 1992). On the other hand, for the winter group, climate and food availability are influencing factors for species composition (MacNally 1996); species of this group may migrate over short distances as well as long distances to avoid extreme environments (Wagner 1981; Carrascal et al. 1987; MacNally 1996; Newton 2007; Suárez-Seoane et al. 2008). Also, wild birds tend to migrate southerly and to lowlands as the temperature decreases (Osbornel and Green 1992), thus providing the rationale that resident birds are included among the indicator species for shorter day lengths, yet are excluded from the indicator species for longer day lengths. As a result, long-distance migratory birds from the north, including Poiceps ruficollis and Anas penelope, together with local migrant species such as Streptopelia orientalis, Anthus hodgsoni, Phoenicurus auroreus, Emberiza rustica, Emberiza elegans (among other resident birds), can be selected as indicator species. The proportion of wetland-dependent birds and resident birds appears to be relatively large, possibly as a result of winter resident birds migrating south and to lowlands (Nsor and Obodai 2014), coupled with a gregarious tendency.

In order to survive, wild birds respond to day length and light conditions when migrating to warmer climates and abundant sources of food (Tewary and Dixit 1983; Misra et al. 2004). This natural response tends to cause seasonal changes in species composition and prevalence (Scott 2010). Therefore, wild bird surveys that do not take seasonal fluctuations into consideration may result in erroneous data concerning species composition and abundance (Canterbury et al. 2000). In particular, for longer-term monitoring, the necessity of synchronizing seasonal timing has been emphasized (Dunn et al. 2006). While wild birds are indicators of environmental conditions and such information is used to evaluate environmental effects (Bibby et al. 2000), this data is limited to seasonal surveys without reference to timing, which in turn may lead to errors in study data. As a result, because development and conservation rely on an observed emergence of species (Mackenzie et al. 2002), the necessity for identifying representative time periods for each season is of great importance (Cyr and Larivee 1980; Mackenzie et al. 2002). Seasons place contrasting demands on animal species that must respond behaviorally and biologically, and forthcoming data must objectively include adjustments in resource consumption as well as migration (Wagner 1981; Carrascal et al. 1987; Newton 2007; Suárez-Seoane et al. 2008). However, most considerations of seasonal changes with respect to such necessities are generally divided into breeding and non-breeding seasons, and dry and wet seasons (Robbins et al. 1986). Seasonal changes of wild bird groups correlate with low winter temperatures (Herrera 1981) and changes in wet and dry seasons (Poulin et al. 1992). On the other hand, Anderson (1972) and Anderson et al. (1981) separate the designated seasons into winter (November or December to February), spring (March to April or June), summer (May to July), late summer (July or August to September), and autumn (September to October or November). Seasonal fluctuations of individual groups clearly show variations for species as well as location and time period, suggesting that further research should be conducted (Cyr and Larivee 1980). This study applied variations in wild bird species composition and abundance in small wetlands of a temperate zone in order to classify spring (April to June), summer (July to September), autumn (October), and winter (November to March), and this corresponds with the 
results of Anderson (1972) and Anderson et al. (1981). However, March, May, June, September, and November are hard to distinguish because these months border seasonal changes. In particular, wild bird migrations vary according to food sources, and thus generally occur during spring or autumn (Lefebvre and Poulin 1996). Spring and summer tend to overlap in May and June, while summer and autumn tend to overlap in September; further research should clarify wild bird profiles in the study area. With regard to survey periods, April was selected for spring, and the months of December/January were selected for winter in order to account for the effects of the increase in biomass in the spring (Avery and Riper III 1989), as well as the decrease in food sources in the winter (Rollfinke and Yahner 1990).

Prior to this research, it was hypothesized that there would be difficulties in fully identifying wild bird migration patterns by performing monthly surveys. This was particularly true for species that stopped briefly over the Korean peninsula while migrating for wintering and breeding. Despite these potential risks, the research was performed because it is believed that arbitrary survey periods only increase margins of error. In particular, long-term monitoring without standardization can lead to problems related to the credibility of the gathered data. Therefore, there exists a need to reorganize survey periods by location and time.

\section{Abbreviations \\ DCA: Detrended correspondence analysis; Fig: Figure; IP: Importance percentage; RD: Relative density; RF: Relative frequency; SAS: Statistical analysis system; TWINSPAN: TWo-way INdicator SPecies Analysis}

\section{Acknowledgements}

Not applicable.

\section{Funding}

Not applicable.

\section{Availability of data and materials}

The datasets during and/or analyzed during the current study are available from the corresponding author on reasonable request.

\section{Authors' contributions}

These authors equally contributed equally to this work. Both authors read and approved the final manuscript.

\section{Ethics approval and consent to participate}

Not applicable

\section{Consent for publication}

Not applicable

\section{Competing interests}

The authors declare that they have no competing interests.

\section{Publisher's Note}

Springer Nature remains neutral with regard to jurisdictional claims in published maps and institutional affiliations.

\section{Author details}

'Department of Landscape Architecture, Gyeongnam National University of Science and Technology, Chiram-dong, Jinju-si, Gyeongsangnam-do 52725, South Korea. ${ }^{2}$ Department of Environment and Landscaping, Sangmyung University, 31 Sangmyungdae-gil, Dongnam-gu, Cheonan-si,

Chungcheongnam-do 31066, South Korea.

Received: 24 June 2018 Accepted: 7 March 2019

Published online: 15 April 2019

\section{References}

Anderson BW. Seasonal variations in forest birds of Western Oregon. Northwest Sci. 1972;46(3):194-206.

Anderson BW, Ohmart RD, Rice J. Seasonal changes in avian density and diversities. Stud Avian Biol. 1981;6:262-4.

Anderson DR. The need to get the basics right in wildlife field studies. Wildl Soc Bull. 2001;29(4):1294-7.

Anderson DR. Response to Engeman: index values rarely constitute reliable information. Wildl Soc Bull. 2003;31(1):288-91.

Avery MC, Riper CV III. Seasonal changes in bird communities of the chaparral and blue-oak woodlands in Central California. Condor. 1989;91:288-95.

Beaumont LJ, McAllan IAW, Hughes L. A matter of timing: changes in the first date of arrival and last date of departure Australian migratory birds. Glob Chang Biol. 2006;12:1339-54.

Best LB. Seasonal changes in detection of individual bird species. Stud Avian Biol. 1981;6:252-61.

Bibby CJ, Burgess ND, Hill DA, Mustoe SH. Bird census technique. San Diego: Academic Press; 2000.

Blake JG. Temporal variation in point counts of birds in a lowland wet forest in Costa Rica. Condor. 1992;94:265-75.

Blake JG, Hanowski JM, Niemi GJ, Collins PT. Annual variation in bird population of mixed conifer-northern hardwood forests. Condor. 1994;96:381-99.

Both C, Bouwhuis S, Lessells CM, Visser ME. Climate change and population declines in a long-distance migratory bird. Nature. 2006;441:81-3.

Bregnballe T, Frederiksen M, Gregersen J. Seasonal distribution and timing of migration of cormorants Phalacrocorax carbo sinensis breeding in Denmark. Bird Study. 1997:44:257-76.

Brower JE, Zar JH, von Ende C. Field and laboratory methods for general ecology. Boston: WCB McGraw-Hill: 1977.

Buckland ST. Point-transect surveys for songbirds: robust methodologies. Auk. 2006;123(2):345-57.

Canterbury GE, Martin TE, Petit DR, Petit LJ, Bradford DF. Bird communities and habitat as ecological indicators of forest condition in regional monitoring. Conserv Biol. 2000;14(2):544-58.

Carrascal LM, Potti J, Sánchez-Aguado FJ. Spatio-temporal organization of the bird communities in two Mediterranean montane forests. Holarct Ecol. 1987; 10:185-92.

Chen CC, Chiang PJ, Shieh BS, Lin CC. Diurnal timing of bird surveys using an acoustic monitoring system in the Shan-Ping forest ecological garden. Taiwan J For Sci. 2011;26(4):313-21.

Cherry SG, Derocher AE, Thiemann GW, Lunn NJ. Migration phenology and seasonal fidelity of an Arctic marine predator in relation to sea ice dynamics. J Anim Ecol. 2013;82:912-21.

Cuervo JJ, Møller AP. Temporal variation in population size of European bird species: effects of latitude and marginality of distribution. PLoS One. 2013; 8(10):1-12.

Curtis JT, McIntosh RP. An upland forest continuum in the Prairie-Forest border region of Wisconsin. Ecology. 1951;31:476-96.

Cyr A, Larivee J. Significance of data collected on birds in Quebec, Canada, by nonstandardized methods. In: Oelke $\mathrm{H}$, editor. Bird census work and nature consenvation. Germany: Dachverbandes Deutshcer Avifaunisten; 1980. p. 300. 66-76.

Dixit AS, Singh NS. Photoperiod as a proximate factor in control of seasonality in the subtropical male tree sparrow, Passer montanus. Front Zool. 2011;8(1):1-12.

Drapeau P, Leduc A, McNeil R. Refining the use of point counts at the scale of individual points in studies of bird-habitat relationships. J Avian Biol. 1999; 30(4):367-82.

Dunn EH, Bart J, Collins BT, Craig B, Dale B, Downes CM, Francis CM, Woodley S, Zorn P. Monitoring bird populations in small geographic areas. Ottawa: Special publication Canadian Wildlife Service; 2006. 
Harrington R, Woiwood I, Sparks TH. Climate change and trophic interactions. Trends Ecol Evol. 1999;14:146-50.

Herrera CM. Organizacion temporal en las communidades de aves. Donana Acta Vertebrata. 1981:8:79-101.

James FC, Johnston RF, Warmer NO, Niemi GJ, Boecklen WJ. The Grinnellian niche of the wood thrush. Am Nat. 1984;124:17-47.

Järvinen O, Vxisxnen RA, Haila Y. Bird census results in different years, stages of the breeding season and times of the day. Ornis Fenn. 1977;54:108-18.

Kar D. Wetlands and lakes of the world. New York: Springer; 2013.

Kim MJ, Lee SD, Kim JS. Selecting the Optimal Research Time for Forest Birds Census in each Season. Korean J Environ Ecol. 2013;27(2):219-229.

Lee SD. Research method for the sustainable ecological restoration of major wetland based on wetland roadmap in Gyeongsangnam-do. Changwon: Gyeongnam green environment council; 2009.

Lee SD, Kim MJ. Development of ecosystem assessment index for the priority management of inland wetland in Gyeongsangnam-do. Pro Kor Soc Env Con. 2010;20(1):89-92.

Lefebvre G, Poulin B. Seasonal abundance of migrant birds and food resources in Panamnian mangrove forests. Wilson Bull. 1996;108(4):748-59.

Lowther PE. The effect of time of day on avian census results. Auk. 1975;94: 380-3.

Mackenzie DI, Nichols JD, Llachman GB, Droege S, Royle JA, Langtimm CA. Estimating site occupancy rates when detection probabilities are less than on. Ecology. 2002;83:2248-55.

MacNally R. A winter's tale: among-year variation in bird community structure in a southeastern Australian forest. Aust J Ecol. 1996;21:280-91.

Marica PP, Francis CM, Mulvihill RS, Moore FR. The influence of climate on the timing and rate of spring bird migration. Oecologia. 2005;142:307-15.

Marsden SJ, Symes CT. Bird richness and composition along and agricultural gradient in New Guinea: the influence of land use, habitat heterogeneity and proximity to intact forest. Austral Ecol. 2008;33:784-93.

Martin TE. Nest predation and nest sites: new perspectives on old patterns. Bioscience. 1993:43:523-32.

Martin TE. Avian life history evolution in relation to nest sites, nest predation and food. Ecol Monogr. 1995;65:101-27.

Martin TE, Li P. Life history traits of open- versus cavity-nesting birds. Ecology. 1992;73:579-92.

McCallum DA. A conceptual guide to detection probability for point counts and other count-based survey methods, USDA Forest Service Gen. Tech. Rep. PSW-GTR-191; 2005. p. 754-61.

Michot TC, Woodin MC, Adair SE, Moser EB. Diurnal time-activity budgets of redhead (Aythya americana) wintering in seagrass beds and coastal ponds in Louisiana and Texas. Hydrobiologia. 2006;567:113-28.

Misra M, Rani S, Singh S, Kumar V. Regulation of seasonality in the migratory male blackheaded bunting (Emberiza melanocephala). Reprod Nutr Dev. 2004;44:341-52.

Nally RM. Monitoring forest bird communities for impact assessment: the influence of sampling intensity and spatial scale. Biol Conserv. 1997;82:355-67.

New Mexico Department of Game and Fish. 2010. Baseline wildlife study guideline.

Newton I. The migration ecology of birds. London: Academic Press; 2007

Nichols JD. Capture-recapture models: using marked animals to study population dynamics. BioScience. 1992;42(2):94-102.

Nsor CA, Obodai EA. Environmental determinants influencing seasonal variations of bird diversity and abundance in wetlands, northern region (Ghana). Ann Exp Biol. 2014;2(3):17-30.

Oliveira LF. Census techniques for birds of prey in large areas of Portugal. Holarctic Birds of Prey; 1998. p. 373-9.

Osbornel WS, Green K. Seasonal changes in composition, abundance and foraging behaviour of birds in the Snowy Mountains. EMU. 1992;92:93-105.

Palmeirim JM, Rabaça JE. A method to analyze and compensate for time-of-day effects on bird counts. J Field Ornithol. 1994;65(1):17-26.

Poulin B, Lefebvre G, McNeil R. Tropical avian penology in relation to abundance and exploitation of food resources. Ecology. 1992;73:2295-309.

Richardson WJ. Bird migration and wind turbines: migration timing, flight behavior and collision risk, National Avian-Wind power Planning meeting III; 1990. p. 132-40.

Robbins CS. Bird activity levels related to weather. Stud Avian Biol. 1981:6:301-10.

Robbins CS, Bystrak D, Geissler PH. The breeding bird survey: its first fifteen years, 1965-1979. Washington D.C: U.S. Fish and Wildlife Service, Resource Publication; 1986
Rollfinke BF, Yahner RH. Effects of time of day and season on winter bird counts. Condor. 1990;92:215-9.

Root TL, Price JT, Hall KR, Schneider SH, Rosenzweigk C, Pounds JA. Fingerprints of global warming on wild animals and plants. Nature. 2003:421:57-60.

Savard JPL, Hooper TD. Influence of survey length and radius size on grassland bird surveys by point counts at Williams Lake, British Columbia, USDA Forest Service Gen. Tech. Rep. PSW-GTR-149; 1995. p. 57-62.

Scott, D.A. 1989. A Directory of Asian Wetlands. http://ramsar.wetlands.org.

Scott G. Essential ornithology. Oxford: Oxford University Press; 2010.

Selmi S, Boulinier T. Does time of season influence bird species number determined from point-count data? A capture-recapture approach. J Field Ornithol. 2003;74(4):349-56.

Seoane J, Villen-Perez S, Carrascal LM. Environmental determinants of seasonal change in bird diversity of Mediterranean oakwoods. Ecol Res. 2013. https:// doi.org/10.1007/s11284-013-1032-2.

Suárez-Seoane S, García de la Morena EL, Morales Prieto MB, Osborne PE, de Juana E. Maximum entropy niche-based modelling of seasonal changes in little bustard (Tetrax tetrax) distribution. Ecol Model. 2008;219:17-29.

Svensson SE. Efficiency of two methods for monitoring bird population levels: breeding bird census contra counts of migrating birds. OIKOS. 1978;30:373-86.

Tewary PD, Dixit AS. Photoperiodic control of the ovarian cycle in the rosefinch, Carpodacus erythrinus. J Exp Zool. 1983;228:537-42.

Underhill LG, Prys-Jones RP, Harrison JA, Martinez P. Seasonal patterns of occurrence of Palaearctic migrants in southern Africa using atlas data. IBIS. 1992;134(SUPPL. 1):99-108.

Verner J, Ritter LV. Hourly variation in morning point counts of birds. Auk. 1986; 103:117-24.

Wagner J. Seasonal change in guild structure: oak woodland insectivorous birds. Ecology. 1981;62:973-81.

Walther GR, Post E, Convey P, Menzel A, Parsnesan C, Beebee TJC, Fromentin JM, Hoegh-Guldberg O, Bairlein F. Ecological responses to recent climate change. Nature. 2002;416:389-95.

Watson DM. The 'standardized search': an improved way to conduct bird survey. Austral Ecology. 2003;28:515-25

Weller F. A comparison of different approaches to monitoring bird density on New Zealand sheep and beef farms. N Z J Ecol. 2012;36(3):1-9.

Wetland International. Guidance on waterbird monitoring methodology: field protocol for waterbird counting; 2010. p. 15.
Ready to submit your research? Choose BMC and benefit from:

- fast, convenient online submission

- thorough peer review by experienced researchers in your field

- rapid publication on acceptance

- support for research data, including large and complex data types

- gold Open Access which fosters wider collaboration and increased citations

- maximum visibility for your research: over $100 \mathrm{M}$ website views per year

At BMC, research is always in progress.

Learn more biomedcentral.com/submissions 